\title{
APPLYING FUZZY MCDM FOR FINANCIAL PERFORMANCE EVALUATION OF IRANIAN COMPANIES
}

\author{
Abdolhamid SAFAEI GHADIKOLAEI ${ }^{\mathrm{a}}$, Saber KHALILI ESBOUEI ${ }^{\mathrm{a}}$, \\ Jurgita ANTUCHEVICIENE ${ }^{\mathrm{b}}$ \\ ${ }^{\mathrm{a}}$ Faculty of Economic and Administrative Sciences, University of Mazandaran, \\ P. O. Box 416, Babolsar, Mazndaran, Iran \\ ${ }^{\mathrm{b}}$ Faculty of Civil Engineering, Vilnius Gediminas Technical University, \\ Sauletekio al. 11, 10223, Vilnius, Lithuania
}

Received 02 July 2013; accepted 13 July 2013

\begin{abstract}
Financial performance evaluation is very important in a highly competitive business environment. Accordingly, an accurate and appropriate performance evaluation is critical. Financial performance indicators reflect the competitiveness of a company and they must be carefully identified in the evaluation process. Generally, accounting measures are used for performance evaluation. However, these measures are not sufficient for performance evaluation in the today's competitive economy. Therefore, value based measures have recently been introduced to express the company value. In this study, a hybrid approach is proposed for financial performance evaluation of automotive companies of Tehran stock exchange (TSE). For this purpose, a hierarchical financial performance evaluation model is structured based on the accounting measures and economic value measures. In this approach Fuzzy Analytic Hierarchy Process (FAHP) is applied to determine weights of criteria. Then the companies are ranked by using Fuzzy VIKOR (VlseKriterijumska Optimizacija I Kompromisno Resenje (in Serbian), Fuzzy Additive Ratio Assessment (ARAS-F) and Fuzzy Complex Proportional Assessment (Fuzzy COPRAS), simultaneously. Also results of three outranking methods are combined by using the mean ranks. The results represented the highest importance of economic value measures than accounting measures in financial performance evaluation of companies. Six companies were ranked applying the proposed approach.
\end{abstract}

Keywords: financial performance, accounting measures, economic value measures, Fuzzy Analytic Hierarchy Process (FAHP), Fuzzy VlseKriterijumska Optimizacija I Kompromisno Resenje (Fuzzy VIKOR), Fuzzy Additive Ratio Assessment (ARAS-F), Fuzzy Complex Proportional Assessment (Fuzzy COPRAS).

Reference to this paper should be made as follows: Safaei Ghadikolaei, A.; Khalili Esbouei, S.; Antucheviciene, J. 2014. Applying fuzzy MCDM for financial performance evaluation of Iranian companies, Journal of Technological and Economic Development of Economy 20(2): 274-291.

JEL Classification: C02, C44, C81, D46, D81, M41.

Corresponding author Abdolhamid Safaei Ghadikolaei

E-mail:ab.safaei@umz.ac.ir 


\section{Introduction}

In a competitive environment, characterized by the scarcity of resources, performance measurement and management play a crucial role (Amado et al. 2012). Accordingly, an accurate and appropriate performance evaluation is very crucial.

Financial aspect is one of the main aspects of the organization performance. Traditionally it should be attractive. Seeing that profit is the main goal of many companies, financial performance and proper evaluation is very important. As financial performance indicators reflect the competitiveness of a company, they must be carefully identified in the evaluation process (Yalcin et al. 2012).

Most of the economical, industrial, financial or political decision problems are multi attribute. Multiple Criteria Decision Making (MCDM) is an advanced field of operation research. It provides decision makers and analysts with a wide range of methodologies, which are overviewed and well-suited to the complexity of economical decision problems (Zavadskas, Turskis 2011). The application of multi-criteria decision making methods significantly improves the robustness of financial analysis and business decisions in general (Balezentis et al. 2012).

In the current research a new multiple criteria model, consisting of Accounting measures and Economic value measures is presented, also a hybrid approach of MCDM methods in fuzzy environment for financial performance evaluation of companies is provided. At first FAHP (Fuzzy Analytic Hierarchy Process) is used to determine the weights of the main criteria and sub criteria. Then fuzzy VIKOR (Fuzzy VlseKriterijumska Optimizacija I Kompromisno Resenje), ARAS-F (Fuzzy Additive Ratio Assessment) and fuzzy COPRAS (Fuzzy Complex Proportional Assessment) are applied simultaneously for ranking the automotive companies traded on Tehran stock exchange in 2002-2011. Final ranking of companies is provided by using mean ranks.

\section{Literature review}

Several studies on financial performance evaluation are focused on ranking the alternatives according to their financial performance measures, included in their comparison environments. Kung et al. (2011) applied fuzzy MCDM methods for selecting the best company, based on financial report analysis. The approach used FAHP to select weighting indicators and fuzzy TOPSIS (Technique for Order Preference by Similarity to Ideal Solution) for outranking the five major airlines. Balezentis et al. (2012) used fuzzy TOPSIS, fuzzy VIKOR and ARAS-F methods for integrated assessment of Lithuanian economy in 2007-2010 periods, based on financial ratios. Ergul and Seyfullahogullari (2012) applied ELECTRE III for ranking of retail companies trading in Istanbul stock exchange (ISE), based on their financial performance in 2008-2010. Lee et al. (2012) performed a comparative study on financial positions of shipping companies in Taiwan and Korea. At first the study applied Entropy to find the relative weights of financial ratios of four companies, and then it used grey relation analysis to rank the companies. Yalcin et al. (2012) constructed a hierarchical structure of the financial performance model for ISE's manufacturing company. The approach used FAHP, VIKOR and 
TOPSIS. Bayrakdaroglu and Yalcin (2012) proposed to use MCDM for strategic financial performance evaluation of ISE. The research applied FAHP for determining the relative significances of criteria and used VIKOR for best company selection. Ignatius et al. (2012) surveyed financial performance of Iran's Automotive Sector based on PROMETHEE II in the study. Cheng et al. (2012) developed an approach combining fuzzy integral with Order Weight Average (OWA) method for evaluating financial performance in the semiconductor industry of Taiwan in 2008. Cement firms are evaluated by taking into consideration only some of the traditional financial performance measures.

Recent studies on the subject are summarized in Table 1.

Table 1. Comparison of the previous studies that have used MCDM methods for financial performance evaluation

\begin{tabular}{|c|c|c|c|}
\hline Study & Objectives & Methods used & Approach used \\
\hline Kung et al. (2011) & $\begin{array}{l}\text { Select the best } \\
\text { company, based } \\
\text { on financial report } \\
\text { analysis }\end{array}$ & $\begin{array}{l}\text { FAHP, fuzzy } \\
\text { TOPSIS }\end{array}$ & $\begin{array}{l}\text { Used FAHP to determine } \\
\text { indicators' weights and the fuzzy } \\
\text { TOPSIS method for outranking } \\
\text { the five major airlines }\end{array}$ \\
\hline $\begin{array}{l}\text { Balezentis et al. } \\
(2012)\end{array}$ & $\begin{array}{l}\text { Integrated assessment } \\
\text { of Lithuanian economy }\end{array}$ & $\begin{array}{l}\text { Fuzzy TOPSIS, } \\
\text { fuzzy VIKOR, } \\
\text { ARAS-F }\end{array}$ & $\begin{array}{l}\text { Applied fuzzy TOPSIS, fuzzy } \\
\text { VIKOR and ARAS-F together for } \\
\text { evaluation of economic sector }\end{array}$ \\
\hline $\begin{array}{l}\text { Ergul and } \\
\text { Seyfullahogullari } \\
\text { (2012) }\end{array}$ & $\begin{array}{l}\text { Ranking of retail } \\
\text { companies trading } \\
\text { in ISE }\end{array}$ & ELECTRE III & $\begin{array}{l}\text { Used ELECTRE III for ranking } \\
\text { five retail companies in Turkey }\end{array}$ \\
\hline Yalcin et al. (2012) & $\begin{array}{l}\text { Financial performance } \\
\text { evaluation of Turkish } \\
\text { manufacturing } \\
\text { company }\end{array}$ & $\begin{array}{l}\text { FAHP, VIKOR, } \\
\text { TOPSIS }\end{array}$ & $\begin{array}{l}\text { Combined FAHP to determine the } \\
\text { weights of criteria, also VIKOR } \\
\text { and TOPSIS for comparatively } \\
\text { ranking of companies }\end{array}$ \\
\hline $\begin{array}{l}\text { Bayrakdaroglu and } \\
\text { Yalcin (2012) }\end{array}$ & $\begin{array}{l}\text { Strategic financial } \\
\text { performance } \\
\text { evaluation of ISE }\end{array}$ & FAHP, VIKOR & $\begin{array}{l}\text { Used FAHP for calculate the } \\
\text { relative importance measures and } \\
\text { VIKOR to select the best company }\end{array}$ \\
\hline $\begin{array}{l}\text { Ignatius et al. } \\
(2012)\end{array}$ & $\begin{array}{l}\text { Financial performance } \\
\text { of Iran's automotive } \\
\text { sector }\end{array}$ & PROMETHEE II & $\begin{array}{l}\text { PROMETHEE II was used to } \\
\text { select the best company }\end{array}$ \\
\hline $\begin{array}{l}\text { Cheng et al. } \\
\text { (2012) }\end{array}$ & $\begin{array}{l}\text { Evaluating of financial } \\
\text { performance in } \\
\text { the semiconductor } \\
\text { industry of Taiwan }\end{array}$ & $\begin{array}{l}\text { Fuzzy Integral, } \\
\text { OWA }\end{array}$ & $\begin{array}{l}\text { Combined fuzzy integral with } \\
\text { Order Weight Average for } \\
\text { financial evaluation }\end{array}$ \\
\hline Lee et al. (2012) & $\begin{array}{l}\text { Survey of financial } \\
\text { positions of shipping } \\
\text { companies in Taiwan } \\
\text { and Korea }\end{array}$ & $\begin{array}{l}\text { Entropy, } \\
\text { Grey Relation } \\
\text { Analysis (GRA) }\end{array}$ & $\begin{array}{l}\text { Used Entropy for determining the } \\
\text { weights of criteria and GRA to } \\
\text { rank the company }\end{array}$ \\
\hline
\end{tabular}

\section{Proposed model}

A new multi criteria model, consisting of Accounting measures and Economic value measures is developed with help of the financial experts and presented in the current study. A combinative approach of MCDM methods in Fuzzy environment for financial performance evaluation of companies also provided. 
Yalcin et al. (2012) constructed hierarchal structure for financial evaluation of manufacturing company on the ground of value based financial performance and accounting based financial performance as main criteria and each having four sub criteria. The model proposed by the Authors differs from Yalcin et al. (2012) model. The proposed model is shown in Figure 1. In this model, four Accounting measures are determined by the finance and Tehran stock exchange expert as the sub-criteria. These measures are Return On Assets (ROA), Return On Equity (ROE), Operating Profit Growth (OPG), also ratio of market price and earnings (P/E). Also, seven Economic value measures are determined as the sub-criteria. These measures are Economic Value Added (EVA), Market Value Added (MVA), Refined Economic Value Added (REVA), True Value Added (TVA), Cash Value Added (CVA), Created Shareholder Value (CSV) and Tobin's Q. Formulation of these sub-criteria measures are briefly explained in the Table 2.

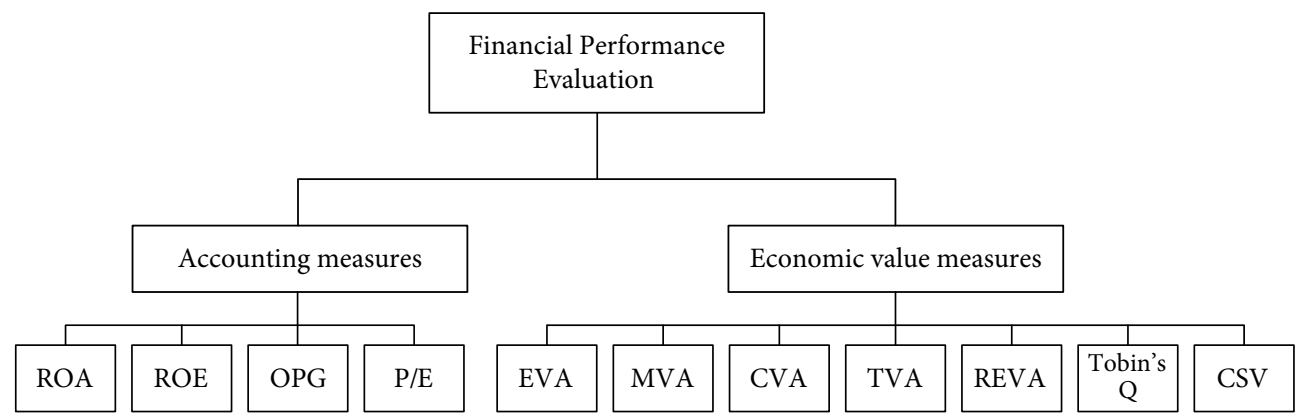

Fig. 1. Hierarchal model for financial performance evaluation of TSE's company

Table 2. Formulation of financial performance evaluation measures

\begin{tabular}{|c|c|c|}
\hline $\begin{array}{l}\text { Financial } \\
\text { performance } \\
\text { measures }\end{array}$ & Formula & Study \\
\hline $\begin{array}{l}\text { Return On } \\
\text { Assets (ROA) }\end{array}$ & $R O A=\frac{\text { Net income available to common stockholder }}{\text { Total assets }}$ & $\begin{array}{l}\text { Yalcin et al. } \\
(2012)\end{array}$ \\
\hline $\begin{array}{l}\text { Return On } \\
\text { Equity }(R O E)\end{array}$ & $R O E=\frac{\text { Net income available to common stockholder }}{\text { Stockholder's equity }}$ & $\begin{array}{l}\text { Yalcin et al. } \\
(2012)\end{array}$ \\
\hline $\begin{array}{l}\text { Operating Profit } \\
\text { Growth (OPG) }\end{array}$ & $O P G=\frac{(\text { Operationg profit })_{t}-(\text { Operationg profit })_{t-1}}{(\text { Operationg profit })_{t-1}}$ & $\begin{array}{l}\text { Ergul and } \\
\text { Seyfullahogullari } \\
(2012)\end{array}$ \\
\hline$P / E$ & $\frac{P}{E}=\frac{\text { Market price per share }}{\text { Earning per share }}$ & $\begin{array}{l}\text { Yalcin et al. } \\
(2012)\end{array}$ \\
\hline $\begin{array}{l}\text { Economic Value } \\
\text { Added (EVA) }\end{array}$ & $\begin{array}{l}E V A_{t}=\text { Net operating profit after tax } \\
\left.\text { (Weighted average cost of capital }_{t} \times \text { Capital employed }_{t-1}\right)\end{array}$ & $\begin{array}{l}\text { Yalcin et al. } \\
\text { (2012) }\end{array}$ \\
\hline $\begin{array}{l}\text { Market Value } \\
\text { Added }(M V A)\end{array}$ & $M V A=$ Total market value - Total capital employed & $\begin{array}{l}\text { Bayrakdaroglu } \\
\text { and Yalcin } \\
(2012)\end{array}$ \\
\hline $\begin{array}{l}\text { Cash Value } \\
\text { Added }(C V A)\end{array}$ & CVA $=$ Gross Cash flows - Economic depreciation - Capital charge & $\begin{array}{l}\text { Yalcin et al. } \\
(2012)\end{array}$ \\
\hline
\end{tabular}


Continued Table 2

\begin{tabular}{|c|c|c|}
\hline $\begin{array}{c}\text { Financial } \\
\text { performance } \\
\text { measures }\end{array}$ & Formula & Study \\
\hline $\begin{array}{l}\text { True Value } \\
\text { Added }(T V A)\end{array}$ & $\begin{array}{l}\text { TVA }=\text { Free cash flow }+ \text { Capital gains }- \text { Market value } \times \\
(1+\text { Weighted average cost of capital })\end{array}$ & $\begin{array}{l}\text { Bayrakdaroglu } \\
\text { and Yalcin } \\
(2012)\end{array}$ \\
\hline $\begin{array}{l}\text { Refined } \\
\text { Economic Value } \\
\text { Added (REVA) }\end{array}$ & $\begin{array}{l}\text { REVA } A_{t}=\text { Net operating profit after tax } \\
\text { Weighted average cost of capital }\left(\text { Mcapital }_{t-1}\right)\end{array}$ & $\begin{array}{l}\text { Hajiabasi et al. } \\
\text { (2012) }\end{array}$ \\
\hline Tobin's $Q$ & Tobin's $Q=\frac{\text { Market value }+ \text { Book value of Liabilities }}{\text { Book value of assets }}$ & $\begin{array}{l}\text { Jones et al. } \\
\text { (2011) }\end{array}$ \\
\hline $\begin{array}{l}\text { Created } \\
\text { Shareholder } \\
\text { Value }(C S V)\end{array}$ & CSV $=$ Market value of equity $\times($ Shareholder return - Cost of equity $)$ & $\begin{array}{l}\text { Largani et al. } \\
\text { (2012) }\end{array}$ \\
\hline
\end{tabular}

\section{MCDM methods}

MCDM is an advanced field of Operation Research that provides decision makers and analysts with a wide range of methodologies, well-suited to the complexity of economical decision problems. Available methodologies and their application for economic decisions are broadly overviewed by Zavadskas and Turskis (2011).

In the presented study four fuzzy MCDM methods were used and applied for evaluation of TSE's companies. At first FAHP was used to determine weights of main criteria and sub criteria. Next the research used fuzzy VIKOR, ARAS-F and fuzzy COPRAS for ranking the companies according to best financial performance.

\subsection{Fuzzy Analytic Hierarchy Process (FAHP)}

Analytic Hierarchy Process (AHP) was introduced by Saaty (1971). In the current research the weights of financial performance criteria are obtained by using extent FAHP method. That is because of the computational easiness and efficiency (Yalcin et al. 2012).

Calculation of FAHP can be described as follows.

Assume that $O=\left\{o_{1}, o_{2}, o_{3}, \ldots, o_{n}\right\}$, be an object set, and $G=\left\{g_{1}, g_{2}, g_{3}, \ldots, g_{m}\right\}$, be a goal set. Each object is taken and extent analysis for each goal is performed, respectively. Therefore, $m$ extent analysis values for each object can be obtained, with the following signs: $\tilde{Q}_{g_{i}}^{1}, \ldots, \tilde{Q}_{g_{i}}^{2}, \ldots, \tilde{Q}_{g_{i}}^{m}, \quad i=1,2, \ldots, \alpha$, where all the $\tilde{Q}_{g_{i}}^{m}(j=1,2, \ldots, m)$ are triangular fuzzy numbers (TFNs).

The further steps of extent FAHP can be given as follows.

Step 1. The value of fuzzy synthetic extent with respect to the $i^{\text {th }}$ object is defined as:

$$
\tilde{S}_{i}=\sum_{j=1}^{m} \tilde{Q}_{g_{i}}^{j} \otimes\left[\sum_{i=1}^{n} \sum_{j=1}^{m} \tilde{Q}_{g_{i}}^{j}\right]^{-1},
$$


perform the fuzzy addition operation of $\beta$ extent analysis values for particular matrix such that:

$$
\sum_{j=1}^{m} \tilde{Q}_{g_{i}}^{j}=\left(\sum_{j=1}^{m} l_{j}, \sum_{j=1}^{m} m_{j}, \sum_{j=1}^{m} u_{j}\right)
$$

and to obtain $\left[\sum_{i=1}^{n} \sum_{j=1}^{m} \tilde{Q}_{g_{i}}^{j}\right]^{-1}$, perform the fuzzy addition operation of $\tilde{Q}_{g_{i}}^{j}(j=1,2, \ldots, \beta)$ values such that:

$$
\sum_{i=1}^{\alpha} \sum_{j=1}^{\beta} \tilde{Q}_{g_{i}}^{j}=\left(\sum_{i=1}^{\alpha} l_{i}, \sum_{i=1}^{\alpha} m_{i}, \sum_{i=1}^{\alpha} u_{i}\right) .
$$

Then the inverse of the vector above is computed:

$$
\left[\sum_{i=1}^{\alpha} \sum_{j=1}^{\beta} \tilde{Q}_{g_{i}}^{j}\right]^{-1}=\left(\frac{1}{\sum_{i=1}^{\alpha} u_{i}}, \frac{1}{\sum_{i=1}^{\alpha} m_{i}}, \frac{1}{\sum_{i=1}^{\alpha} l_{i}}\right) .
$$

Step 2. As $\tilde{Q}_{1}=\left(l_{1}, m_{1}, u_{1}\right)$ and $\tilde{Q}_{2}=\left(l_{2}, m_{2}, u_{2}\right)$ are two triangular fuzzy numbers, the degree of possibility of $\tilde{Q}_{2} \geq \tilde{Q}_{1}$ defined as:

$$
V\left(\tilde{Q}_{2} \geq \tilde{Q}_{1}\right)=\sup _{y \geq x}\left[\min \left(\mu_{\tilde{Q}_{1}}(x), \mu_{\tilde{Q}_{2}}(y)\right)\right]
$$

and can be equivalently expressed as follows:

$$
V\left(\tilde{Q}_{2} \geq \tilde{Q}_{1}\right)=h g t\left(\tilde{Q}_{1} \cap \tilde{Q}_{2}\right)=\mu_{\tilde{Q}_{2}}(d)=\left\{\begin{array}{ll}
1, & \text { if } m_{2} \geq m_{1} \\
0, & \text { if } l_{1} \geq u_{2} \\
\frac{l_{1}-u_{2}}{\left(m_{2}-u_{2}\right)-\left(m_{1}-l_{1}\right)}, O . W
\end{array},\right.
$$

where $d$ is the ordinate of the highest intersection point $D$ between $\mu_{\tilde{Q}_{1}}$ and $\mu_{\tilde{Q}_{2}}$ (Fig. 2).

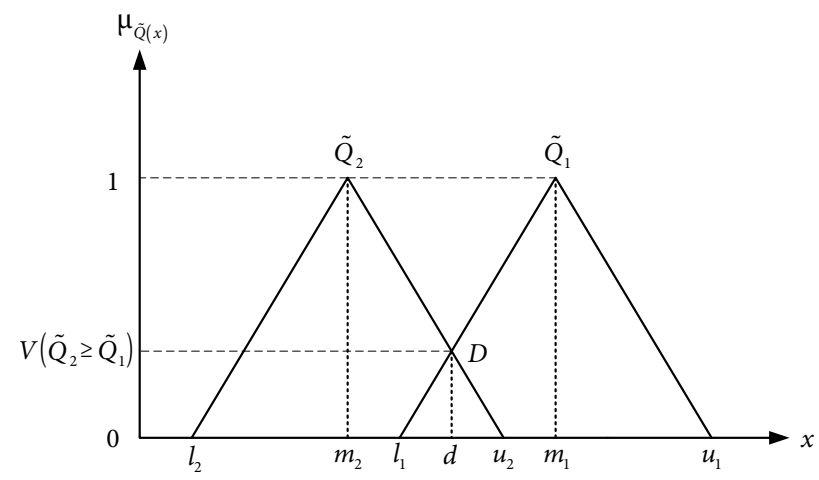

Fig. 2. The intersection between $\tilde{Q}_{1}$ and $\tilde{Q}_{2}$ 
To compare $\tilde{Q}_{1}$ and $\tilde{Q}_{2}$, we need both values of $V\left(\tilde{Q}_{1} \geq \tilde{Q}_{2}\right)$ and $V\left(\tilde{Q}_{2} \geq \tilde{Q}_{1}\right)$.

Step 3. The degree possibility for a convex fuzzy number to be greater than $k$ convex fuzzy $\tilde{Q}_{1}(i=1,2, \ldots, k)$ numbers can be defined by:

$$
\begin{aligned}
& V\left(\tilde{Q} \geq \tilde{Q}_{1}, \tilde{Q}_{2}, \ldots, \tilde{Q}_{k}\right)=V\left[\left(\tilde{Q} \geq \tilde{Q}_{1}\right) \text { and }\left(\tilde{Q} \geq \tilde{Q}_{2}\right) \ldots \text { and }\left(\tilde{Q} \geq \tilde{Q}_{k}\right)\right]= \\
& \min V\left(\tilde{Q} \geq \tilde{Q}_{1}\right), i=1,2,3, \ldots, k
\end{aligned}
$$

Assume that $d^{\prime}\left(P_{i}\right)=\min V\left(S_{i} \geq S_{k}\right)$ for $k=1,2, \ldots, n ; k \neq i$. Then the weight vector is given by:

$$
W^{\prime}=\left(d^{\prime}\left(P_{1}\right), d^{\prime}\left(P_{2}\right), \ldots, d^{\prime}\left(P_{n}\right)\right)^{T},
$$

where $P_{i}(i=1,2, \ldots, n)$ are $n$ elements.

Step 4. Via normalization, the normalized weight vectors are:

$$
W=\left(d\left(P_{1}\right), d\left(P_{2}\right), \ldots, d\left(P_{n}\right)\right)^{T},
$$

where $W$ is a non-fuzzy number.

\subsection{Fuzzy MCDM outranking methods}

In this study three fuzzy outranking methods are used. Let us assume the fuzzy decision making matrix $\tilde{D}=\tilde{d}_{i j}$, where $i=1,2, \ldots, m$ and $j=1,2, \ldots, n$ represent the number of alternatives and criteria, respectively. In this study $m=6$ and $n=11$. The $j^{\text {th }}$ criterion of the $i^{\text {th }}$ alternative is represented by triangular fuzzy number $\tilde{d}_{i j}=\left(d_{i j_{1}}, d_{i j_{2}}, d_{i j_{3}}\right)$. Also each $j^{\text {th }}$ criterion is assigned with respective coefficient of significance $\tilde{w}_{j}$, that it obtained by FAHP. Benefit criteria are members of benefit criteria set $B$, while cost criteria are members of respective set $C$.

\subsubsection{Fuzzy VIKOR}

Based on crisp VIKOR that was introduced by Opricovic (1998), also Opricovic and Tzeng (2004), fuzzy VIKOR was developed later and presented in many studies (Antucheviciene et al. 2011, 2012; Chou, Cheng 2012; Vinodh et al. 2013). VIKOR is based on measuring the closeness to the ideal alternative according to separate cases of $L_{p}$ metric (Balezentis et al. 2012). Computing of fuzzy VIKOR consists of following steps:

Step 1. The fuzzy best values $\tilde{f}_{j}^{+}$and the fuzzy worst values $\tilde{f}_{j}^{-}$are found:

$$
\begin{array}{ll}
\tilde{f}_{j}^{+}=\max _{i} \tilde{d}_{i j}, \quad & \tilde{f}_{j}^{-}=\min _{i} \tilde{d}_{i j}, \forall j \in B, \\
\tilde{f}_{j}^{+}=\min _{i} \tilde{d}_{i j}, & \tilde{f}_{j}^{-}=\max _{i} \tilde{d}_{i j}, \forall j \in C .
\end{array}
$$

Step 2. The distances of each alternative from the ideal one are determined:

$$
\begin{gathered}
\tilde{S}_{i}=\sum_{i=1}^{n} \tilde{w}_{j}\left(\tilde{f}_{j}^{+}-\tilde{d}_{i j}\right) /\left(\tilde{f}_{j}^{+}-\tilde{f}_{j}^{-}\right), \forall i ; \\
\tilde{R}_{i}=\max \left[\tilde{w}_{j}\left(\tilde{f}_{i}^{+}-\tilde{d}_{i j}\right) /\left(\tilde{f}_{j}^{+}-\tilde{f}_{j}^{-}\right)\right], \forall i .
\end{gathered}
$$


Step 3. The reference point is defined by computing values of $\tilde{S}^{+}, \tilde{S}^{-}, \tilde{R}^{+}$, and $\tilde{R}^{-}$, which, in turn, enable to obtain the final summarizing ratio $\tilde{Q}_{i}$ :

$$
\begin{gathered}
\tilde{S}^{+}=\min _{i} \tilde{S}_{i}, \tilde{S}^{-}=\max _{i} \tilde{S}_{i}, \tilde{R}^{+}=\min _{i} \tilde{R}_{i}, \tilde{R}^{-}=\max _{i} \tilde{R}_{i} \\
\tilde{Q}_{i}=v\left(\tilde{S}_{i}-\tilde{S}^{+}\right) /\left(\tilde{S}^{-}-\tilde{S}^{+}\right)+(1-v)\left(\tilde{R}_{i}-\tilde{R}^{+}\right) /\left(\tilde{R}^{-}-\tilde{R}^{+}\right), \forall i .
\end{gathered}
$$

Step 4. Defuzzifying triangular fuzzy numbers $\tilde{S}_{i}, \tilde{R}_{i}$, and $\tilde{Q}_{i}$ into crisp values. A center of area (COA) defuzzification method is used to determine the best non-fuzzy performance $(B N P)$. The BNP value of the triangular fuzzy number $\left(l_{i}, m_{i}, u_{i}\right)$ can be found by the following equation:

$$
B N P_{i}=\frac{l_{i}+m_{i}+u_{i}}{3}, \forall i
$$

Step 5. Ranking the alternatives, sorting by the values $S_{i}, R_{i}$ and $Q_{i}$, in decreasing order. The results are three ranking lists.

Step 6. Proposing as a compromise solution, for given criteria weights, the alternative $\left(a^{\prime}\right)$, which is the best ranked by the measure $Q$ if the following two conditions are satisfied:

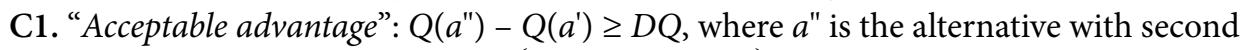
position in the ranking list by $Q ; D Q=\frac{\left(\max _{i} Q_{i}-\min _{i} Q_{i}\right)}{m-1} ; m$ is the number of alternatives (Chou, Cheng 2012).

C2. "Acceptable stability in decision making": Alternative $a$ ' must also be the best ranked by $S$ or/and $R$. This compromise solution is stable within a decision making process, which could be: "voting by majority rule" (when $v>0.5$ is needed), or "by consensus" $v \approx 0.5$, or "with veto" $(v<0.5)$. Here, $v$ is the weight of the decision making strategy "the majority of criteria" (or "the maximum group utility").

If one of the conditions is not satisfied, then the set of compromise solutions is proposed, which consists of:

Alternatives $a^{\prime}$ and $a^{\prime \prime}$, if only the condition C2 is not satisfied;

Alternatives $a^{\prime}, a^{\prime \prime}, \ldots, a^{(k)}$, if the condition $\mathrm{C} 1$ is not satisfied; $a^{(k)}$ is determined by the relation $Q\left(a^{(k)}\right)-Q\left(a^{\prime}\right) \approx D Q$, the positions of these alternatives are "in closeness".

\subsubsection{ARAS-F}

The ARAS-F is based on comparing every alternative with the hypothetic ideal one (Turskis, Zavadskas 2010; Kersuliene, Turskis 2011; Balezentis et al. 2012). The calculation steps of ARAS-F are as presented below.

Step 1. In this method the ideal alternative is described in the following way:

$$
\tilde{d}_{0 j}=\max _{i} d_{i j_{3}}, \forall j \in B, \quad \tilde{d}_{0 j}=\min _{i} d_{i j_{1}}, \forall j \in C .
$$


Step 2. The normalized values $\overline{\tilde{d}}_{i j}$ are obtained:

$$
\begin{aligned}
& \overline{\tilde{d}}_{i j}=\frac{\tilde{d}_{i j}}{\sum_{i=0}^{m} \tilde{d}_{i j}}, \forall j \in B, \\
& \overline{\tilde{d}}_{i j}=\frac{1 / \tilde{d}_{i j}}{\sum_{i=0}^{m} 1 / \tilde{d}_{i j}}, \forall j \in C .
\end{aligned}
$$

Step 3. Each $\overline{\tilde{d}}_{i j}$ is weighted by computing elements of the weighted-normalized matrix:

$$
\hat{\tilde{d}}_{i j}=\overline{\tilde{d}}_{i j} \times \tilde{w}_{j}, \forall j, i
$$

where $\tilde{w}_{j}$ is coefficient of significance and $\hat{\tilde{d}}_{i j}$ is the weighted-normalized value of the $j^{\text {th }}$ criterion of the $i^{\text {th }}$ alternative.

The overall utility $\tilde{S}_{i}$ of the $i^{\text {th }}$ alternative is computed in the following way:

$$
\tilde{S}_{i}=\sum_{j=1}^{n} \hat{\tilde{d}}_{i j}, \forall i .
$$

Since $\tilde{S}_{i}=\left(s_{i 1}, s_{i 2}, s_{i 3}\right), i=0,1, \ldots, m$, is a fuzzy number, the COA method is applied for defuzzification:

$$
S_{i}=\frac{s_{i 1}+s_{i 2}+s_{i 3}}{3}, \forall i
$$

Finally, the relative utility of the $i$ th alternative $K_{i}$ is found:

$$
K_{i}=\frac{S_{i}}{S_{0}}, \forall i,
$$

where $K_{i} \in[0,1]$. The best alternative is found by maximizing value of $K_{i}$.

\subsubsection{Fuzzy COPRAS}

COPRAS method was first put forward by Zavadskas and Kaklauskas (1996). Fuzzified COPRAS was presented by Zavadskas and Antucheviciene (2007). It is used to prioritize the alternatives on the basis of several criteria along with the associated criteria weights. This method works on a stepwise ranking and evaluation procedure of the alternatives in terms of their significance and utility degree. Crisp or modified method for uncertain environment has been successfully applied in for maintenance strategy or performance evaluation, for selection of effective decisions in construction or management (Yazdani et al. 2011; Kanapeckiene et al. 2011; Fouladgar et al. 2012; Tamosaitiene, Gaudutis 2013; Das et al. 2012; Mulliner et al. 2013; Staniunas et al. 2013; Palevicius et al. 2013).

Calculations of fuzzy COPRAS can be described as follows:

Step 1. Normalize the values of $\tilde{d}_{i j}$ by using the following formula:

$$
\overline{\tilde{d}}_{i j}=\frac{\tilde{d}_{i j}}{\sum_{i=1}^{m} \tilde{d}_{i j}}, \forall j .
$$


Step 2. Determine the weighted normalized decision matrix:

$$
\hat{\tilde{d}}_{i j}=\overline{\tilde{d}}_{i j} \times \tilde{w}_{j}, \forall j, i,
$$

where $\overline{\tilde{d}}_{i j}$ is the normalized performance value of $i^{\text {th }}$ alternative on $j^{\text {th }}$ criteria and $w_{j}$ is the associated weight of the $j^{\text {th }}$ criteria.

Step 3. The sums $S_{i}^{+}$and $S_{i}^{-}$of weighted normalized values are calculated for both beneficial and non-beneficial criteria, respectively. For benefit criteria, higher value is better and for cost criteria, lower value is better for the attainment of goal. $S_{i}^{+}$and $S_{i}^{-}$are calculated using the following equations:

$$
\begin{aligned}
& \tilde{S}_{i}^{+}=\sum_{j=1}^{k} \hat{\tilde{d}}_{i j} \forall j \in B, \\
& \tilde{S}_{i}^{-}=\sum_{j=K+1}^{k} \hat{\tilde{d}}_{i j}, \forall j \in C .
\end{aligned}
$$

Step 4. Determine the relative importance or priorities of the candidate alternative by the following equation:

$$
\tilde{H}_{i}=\tilde{S}_{i}^{+}+\frac{\sum_{i=1}^{m} \tilde{S}_{i}^{-}}{\tilde{S}_{i}^{-} \sum_{i=1}^{m} \frac{1}{\tilde{S}_{i}^{-}}}, \forall i .
$$

Step 5. Since $\tilde{H}_{i}=\left(h_{i 1}, h_{i 2}, h_{i 3}\right), i=0,1, \ldots, m$, is a fuzzy number, the COA method is applied for defuzzification:

$$
H_{i}=\frac{h_{i 1}+h_{i 2}+h_{i 3}}{3}, \forall i
$$

where the relative importance $H_{i}$ of an alternative shows the extent of satisfaction attained by that alternative. Among the alternatives, one with the highest $H_{i}$ value is the best alternative.

Step 6. Calculate the performance index $\left(P I_{i}\right)$ of each alternative as:

$$
P I_{i}=\frac{H_{i}}{H_{\max }} \cdot 100 \% \text {. }
$$

Here $H_{\max }$ is the maximum value of relative importance. $P I_{i}$ value is utilized to get complete ranking of the alternatives.

\section{Applications of the proposed approach}

The aim of this study is to present a fuzzy approach to evaluate the financial performance of the companies in the Iran, traded on TSE, by using both Accounting measures and Economic value measures together and in a fuzzy environment. This approach was applied for evaluation of automotive companies of TSE in 2002-2011, i.e. in a period of ten years. Six companies were selected for this study. For this period of the research, annual financial statements of companies which passed independent external auditing are considered. Data was gathered from the TSE's Database and using Rahavard Novin software. 


\subsection{Determining the weights of criteria}

To evaluate the importance of the main criteria and sub-criteria and compose the fuzzy pairwise matrix, expert group (decision makers) utilized the membership function of linguistic scale. The scale is presented in Table 3.

Table 3. Membership function of linguistic scale (Chou, Cheng 2012)

\begin{tabular}{ccc}
\hline Linguistic scale & $\begin{array}{c}\text { Positive triangular } \\
\text { fuzzy numbers }\end{array}$ & $\begin{array}{c}\text { Positive reciprocal triangular } \\
\text { fuzzy numbers }\end{array}$ \\
\hline Absolutely importance & $(8,9,10)$ & $(1 / 10,1 / 9,1 / 8)$ \\
\hline Intermediate & $(7,8,9)$ & $(1 / 9,1 / 8,1 / 7)$ \\
\hline Very strongly & $(6,7,8)$ & $(1 / 8,1 / 7,1 / 6)$ \\
\hline Intermediate & $(5,6,7)$ & $(1 / 7,1 / 6,1 / 5)$ \\
\hline Strong & $(4,5,6)$ & $(1 / 5,1 / 4,1 / 3)$ \\
\hline Intermediate & $(3,4,5)$ & $(1 / 4,1 / 3,1 / 2)$ \\
\hline Weakly & $(2,3,4)$ & $(1 / 3,1 / 2,1)$ \\
\hline Intermediate & $(1,2,3)$ & $(1,1,1)$ \\
\hline Equally importance & $(1,1,1)$ &
\end{tabular}

The pairwise comparison scores have been carried out by financial experts. Experts were asked to make pairwise comparisons for all evaluation criteria based on Table 2. In this study for testing the consistency ratio (CR) of fuzzy pairwise matrix, Lin (2010) approach was used. If the CR is greater than 0.1 , the result is not consistent, and the pair-wise comparison matrix must be revised by the evaluator. Let $\tilde{R}=\left[\tilde{r}_{i j}\right]$ be a fuzzy judgment matrix with triangular fuzzy number $\tilde{r}_{i j}=\left(l_{i j}, m_{i j}, u_{i j}\right)$ and form $R=\left[m_{i j}\right]$. If $R$ is consistent, then $\tilde{R}$ is consistent (Lin 2010).

After computing the result of each evaluator's assessment, Lin (2010) approach was used to obtain the consistency ratio of each expert's pare wise matrix. Consistency ratio values are less than the acceptable threshold value (i.e. CR $<0.1$ ).

The overall results were obtained by taking the geometric mean of individual evaluations. Combined pairwise matrix of main criteria with their weights from FAHP is shown in Table 4.

Table 4. The fuzzy evaluation matrix with respect to the goal

\begin{tabular}{cccc}
\hline & Accounting measures & Economic value measures & Weights \\
\hline Accounting measures & $(1,1,1)$ & $(0.3102,0.4518,0.8409)$ & 0.2332 \\
\hline Economic value measures & $(1.1892,2.2134,3.2237)$ & $(1,1,1)$ & 0.7668 \\
\hline
\end{tabular}

With respect to the results, Economic value measures are more important than Accounting measures in financial performance evaluation of TSE's companies. Table 5 shows the weights of the sub criteria were obtained by FAHP. CVA, TVA, REVA have highest weight among sub criteria, respectively, so TSE's companies should Pay special attention to this measures about their financial performance. 
Table 5. Weights of sub criteria obtained from FAHP

\begin{tabular}{cccc}
\hline Sub criteria & Local Weights & Total Weights & Rank \\
\hline$R O A$ & 0.2431 & 0.0567 & 10 \\
\hline$R O E$ & 0.2089 & 0.0487 & 11 \\
\hline$O P G$ & 0.2689 & 0.0627 & 9 \\
\hline$P / E$ & 0.2791 & 0.0651 & 8 \\
\hline$E V A$ & 0.1040 & 0.0797 & 6 \\
\hline$M V A$ & 0.1359 & 0.1042 & 4 \\
\hline$C V A$ & 0.1823 & 0.1398 & 1 \\
\hline$T V A$ & 0.1764 & 0.1353 & 2 \\
\hline$R E V A$ & 0.1668 & 0.1279 & 7 \\
\hline Tobin's $Q$ & 0.1031 & 0.0791 & 5 \\
\hline$C S V$ & 0.1315 & 0.01008 &
\end{tabular}

\subsection{Ranking the alternatives}

The following approach was used for convert crisp numbers of financial measures into fuzzy numbers. As for time series data, when $x_{i j}$ is the value of $j^{\text {th }}$ criterion of $i^{\text {th }}$ alternative in each year (2002-2011), a fuzzy number can represent the dynamics of certain indicator during past $t=10$ periods (Balezentis et al. 2012):

$$
\left(\operatorname{Min}\left(x_{i j}\right), \frac{\sum_{i=1}^{10} x_{i j}}{10}, \operatorname{Max}\left(x_{i j}\right)\right), \forall i, \forall j .
$$

Let us assume $\tilde{C}_{i j}=\left(c_{i j_{1}}, c_{i j_{2}}, c_{i j_{3}}\right)$ are the initial values of each criterion, obtained using Eq. (28). As some of values in each criterion were negative, for preventing of any problem in computation, all the values in each criterion are transformed to positive values by the following equation:

$$
\tilde{d}_{i j}=\left(c_{i j_{1}}-\min c_{i j_{1}}+1, c_{i j 2}-\min c_{i j_{1}}+1, c_{i j 3}-\min c_{i j_{1}}+1\right), \forall i, \forall j .
$$

Indeed the above equation is the same as $\tilde{d}_{i j}=\left(d_{i j_{1}}, d_{i j_{2}}, d_{i j 3}\right)$ in the computation steps of methods.

As it was mentioned, six Iranian automotive companies are analysed. Initial data on their financial performance measurements is presented in Annex 1.

At first fuzzy VIKOR is used to rank the companies. Usually in other studies, the value of $v$ is considered 0.5 , but in this study different values of $v$ are considered and ranking of $Q$ was obtained from average of different values of $Q_{i}$. Table 6 shows the results of fuzzy VIKOR with different values of $v$. 
Table 6. The results of fuzzy VIKOR

\begin{tabular}{|c|c|c|c|c|c|c|}
\hline Company & $\begin{array}{c}v=0 \\
Q_{i}\end{array}$ & $\begin{array}{c}v=0.25 \\
Q_{i}\end{array}$ & $\begin{array}{c}v=0.5 \\
Q_{i}\end{array}$ & $\begin{array}{c}v=0.75 \\
Q_{i}\end{array}$ & $\begin{array}{c}v=1 \\
Q_{i}\end{array}$ & $\begin{array}{c}\text { Average } \\
\text { Rank }\end{array}$ \\
\hline IKCO & 0.8853 & 0.7994 & 0.7134 & 0.6275 & 0.5415 & 2.4 \\
\hline KAV & 1.3953 & 1.4116 & 1.4279 & 1.4442 & 1.4604 & 6 \\
\hline $\mathrm{PKO}$ & 1.3705 & 1.3155 & 1.2604 & 1.2054 & 1.1503 & 5 \\
\hline SIPA & 1.1878 & 1.1183 & 1.0488 & 0.9793 & 0.9098 & 4 \\
\hline RENA & 0.0021 & 0.0022 & 0.0023 & 0.0024 & 0.0026 & 1 \\
\hline BHMN & 0.7393 & 0.7493 & 0.7593 & 0.7693 & 0.7793 & 2.6 \\
\hline \multicolumn{7}{|c|}{ Ranking results } \\
\hline Company & $\begin{array}{c}\text { Rank obtained } \\
\text { from } Q_{i}\end{array}$ & $S_{i}$ & Rank & $R_{i}$ & Rank & \\
\hline IKCO & 2 & 1.4078 & 2 & 0.8199 & 3 & \\
\hline KAV & 6 & 1.9485 & 6 & 0.8634 & 4 & \\
\hline $\mathrm{PKO}$ & 5 & 1.7295 & 5 & 0.8780 & 5 & \\
\hline SIPA & 4 & 1.7112 & 4 & 0.8901 & 6 & \\
\hline RENA & 1 & 0.8693 & 1 & 0.2764 & 1 & \\
\hline BHMN & 3 & 1.4827 & 3 & 0.6463 & 2 & \\
\hline
\end{tabular}

As one can see from the Table 6, RENA has the minimum score with respect to the $Q$ values, also conditions of Acceptable advantage and Acceptable stability in decision making are satisfied by this alternative. Accordingly, RENA is chosen as the best company in terms of financial performance among other companies.

Table 7 shows the results obtained from ARAS-F and fuzzy COPRAS together. In this proposed model all the criteria are of benefit, while for applying COPRAS a cost criterion is necessary. Hence values of one criterion $(O P G)$ for all alternatives have been reversed for feasibility of using fuzzy COPRAS method for this study.

Table 7. The results of ARAS-F and fuzzy COPRAS

\begin{tabular}{cccccc}
\hline Company & $K_{i}$ & Rank & $H_{i}$ & $P I_{i}$ & Rank \\
\hline IKCO & 0.3251 & 2 & 0.2384 & 57.05 & 2 \\
\hline KAV & 0.0760 & 5 & 0.0772 & 18.48 & 5 \\
\hline PKO & 0.0624 & 6 & 0.0734 & 17.56 & 6 \\
\hline SIPA & 0.2118 & 3 & 0.1834 & 43.90 & 4 \\
\hline RENA & 0.4104 & 1 & 0.4178 & 100.00 & 1 \\
\hline BHMN & 0.1706 & 4 & 0.1930 & 46.19 & 3 \\
\hline
\end{tabular}

As it shown, RENA is the best company with respect to the financial performance among automotive companies traded on TSE in 2002-2011.

Finally, for composing the final order of priority among all alternatives, average of obtained ranks of the three methods has been considered. Table 8 shows the final ranks of the companies. 
Table 8. Final Rankings of the companies

\begin{tabular}{cccccc}
\hline Company & Fuzzy VIKOR & ARAS-F & Fuzzy COPRAS & Average Rank & Final Ranks \\
\hline IKCO & 2 & 2 & 2 & 2 & 2 \\
\hline KAV & 6 & 5 & 5 & 5.33 & 5 \\
\hline PKO & 5 & 6 & 6 & 5.67 & 6 \\
\hline SIPA & 4 & 3 & 4 & 3.67 & 4 \\
\hline RENA & 1 & 1 & 1 & 1 & 1 \\
\hline BHMN & 3 & 4 & 3 & 3.33 & 3 \\
\hline
\end{tabular}

\section{Conclusions}

Financial ratios provide useful quantitative financial information about performance of a company. In this context, this study displays a fuzzy hybrid approach for the financial performance evaluation of companies.

In the proposed approach, at first FAHP is used to determine the weights of the main-criteria and also sub-criteria. Then fuzzy VIKOR, ARAS-F and fuzzy COPRAS are used for ranking the companies based on financial performance, simultaneously. Finally, by combining the results of these three methods via mean ranks, final ranking of the companies can be presented.

In today's world economy, good financial situations provide company's competitive advantage. Many studies in the literature involving MCDM procedures use only the traditional financial ratios. In this study both of Accounting measures and Economic value measures have been used for financial performance evaluation. Results showed that Economic value measures are more important than Accounting measures for companies' evaluation. Also, to achieve better performance evaluation, companies should pay more attention to CVA, TVA, REVA and other measures in line with calculated their relative significances.

A case study of automotive parts producer companies traded on TSE in 2002-2011 is presented. The proposed approach is applied for measuring financial performance of companies in uncertain environment with respect to multiple criteria.

Further study can include some other Economic value measures like shareholder value added (SVA), equity economic value added (EEVA) and other for performance measures. In addition to the proposed methods in this study, some other MCDM methods can be used in this area.

\section{References}

Amado, C. A. F.; Santos, S. P.; Marques, P. M. 2012. Integrating the Data Envelopment Analysis and the Balanced Scorecard approach for enhanced performance assessment, Omega 40(3): 390-403. http://dx.doi.org/10.1016/j.omega.2011.06.006

Antucheviciene, J.; Zakarevicius, A.; Zavadskas, E. K. 2011. Measuring congruence of ranking results applying particular MCDM methods, Informatica 22(3): 319-338.

Antucheviciene, J.; Zavadskas, E. K.; Zakarevicius, A. 2012. Ranking redevelopment decisions of derelict buildings and analysis of ranking results, Economic Computation and Economic Cybernetics Studies and Research 46(2): 37-62. 
Balezentis, A.; Balezentis, T.; Misiunas, A. 2012. An integrated assessment of Lithuanian economic sectors based on financial ratios and fuzzy MCDM methods, Technological and Economic Development of Economy 18(1): 34-53. http://dx.doi.org/10.3846/20294913.2012.656151

Bayrakdaroglu, A.; Yalcin, N. 2012. Strategic financial performance evaluation of the Turkish companies traded on ISE, Ege Academic Review 12(4): 529-539.

Cheng, C. H.; Chen, C. T.; Huang, S. F. 2012. Combining fuzzy integral with order weight average (OWA) method for evaluating financial performance in the semiconductor industry, African Journal of Business Management 6(21): 6358-6368.

Chou, W. C.; Cheng, Y. P. 2012. A hybrid fuzzy MCDM approach for evaluating website quality of professional accounting firms, Expert Systems with Applications 39(3): 2783-2793. http://dx.doi.org/10.1016/j.eswa.2011.08.138

Das, M. C.; Sarkar, B.; Ray, S. 2012. A framework to measure relative performance of Indian technical institutions using integrated fuzzy AHP and COPRAS methodology, Socio-Economic Planning Sciences 46(3): 230-241.

Ergul, N.; Seyfullahogullari, C. A. 2012. The ranking of retail companies trading in ISE, European Journal of Scientific Research 70(1): 29-37.

Fouladgar, M. M.; Yazdani-Chamzini, A.; Lashgari, A.; Zavadskas, E. K.; Turskis, Z. 2012. Maintenance strategy selection using AHP and COPRAS under fuzzy environment, International Journal of Strategic Property Management 16(1): 85-104. http://dx.doi.org/10.3846/1648715X.2012.666657

Hajiabasi, M.; Kaviani, M.; Samadi Largani, N.; Samadi Largani, M.; Montazeri, H. 2012. Comparison of information content value creation measures (EVA, REVA, MVA, SVA, CSV and CVA) and accounting measures (ROA, ROE, EPS, CFO) in predicting the Shareholder Return (SR) evidence from Iran stock exchange, ARPN Journal of Science and Technology 2(5): 517-521.

Ignatius, J.; Behzadian, M.; Malekan, H. S.; Lalitha, D. 2012. Financial performance of Iran's automotive sector based on PROMETHEE II, Proceedings of the 2012 IEEE ICMIT, 11-13 June, 2012, 35-38. http://dx.doi.org/10.1109/ICMIT.2012.6225775

Jones, J. S.; Miller, S. A.; Yeager, T. J. 2011. Charter value, Tobin’s Q and bank risk during the subprime financial crisis, Journal of Economics and Business 63(5): 372-391.

http://dx.doi.org/10.1016/j.jeconbus.2010.10.003

Kanapeckiene, L.; Kaklauskas, A.; Zavadskas, E. K.; Raslanas, S. 2011. Method and system for multiattribute market value assessment in analysis of construction and retrofit projects, Expert Systems with Applications 38(11): 14196-14207.

Kersuliene, V.; Turskis, Z. 2011. Integrated fuzzy multiple criteria decision making model for architect selection, Technological and Economic Development of Economy 17(4): 645-666. http://dx.doi.org/10.3846/20294913.2011.635718

Kung, J. Y.; Chuang, T. N.; Ky, C. M. 2011. A fuzzy MCDM method to select the best company based on financial report analysis, IEEE International Conference on Fuzzy Systems, 27-30 June, 2011, Taipei, Taiwan, 2013-2017.

Largani, M. S.; Kaviani, M.; Abdollahpour, A. 2012. A review of the application of the concept of Shareholder Value Added (SVA) in financial decisions, Procedia - Social and Behavioural Sciences 40: 490-497.

Lee, P. T. W.; Lin, C. W.; Shin, S. H. 2012. A comparative study on financial positions of shipping companies in Taiwan and Korea using entropy and grey relation analysis, Expert Systems with Applications 39(5): 5649-5657. http://dx.doi.org/10.1016/j.eswa.2011.11.052

Lin, H. F. 2010. An application of Fuzzy AHP for evaluating course website quality, Computers \& Education 54(4): 877-888. http://dx.doi.org/10.1016/j.compedu.2009.09.017

Mulliner, E.; Smallbone, K.; Maliene, V. 2013. An assessment of sustainable housing affordability using a multiple criteria decision making method, Omega 41(2): 270-279.

http://dx.doi.org/10.1016/j.omega.2012.05.002 
Opricovic, S. 1998. Multi-criteria optimization of civil engineering systems: PhD Dissertation. Belgrade, Faculty of Civil Engineering.

Opricovic, S.; Tzeng, G. H. 2004. Compromise solution by MCDM methods: a comparative analysis of VIKOR and TOPSIS, European Journal of Operational Research 156(2): 445-455. http://dx.doi.org/10.1016/S0377-2217(03)00020-1

Palevicius, V.; Paliulis, G. M.; Venckauskaite, J.; Vengrys, B. 2013. Evaluation of the requirement for passenger car parking spaces using multi-criteria methods, Journal of Civil Engineering and Management 19(1): 49-58. http://dx.doi.org/10.3846/13923730.2012.727463

Saaty, T. L. 1971. How to make a decision: the analytic hierarchy process, European Journal of Operational Research 40: 9-10.

Staniunas, M.; Medineckiene, M.; Zavadskas, E. K.; Kalibatas, D. 2013. To modernize or not: Ecological-economical assessment of multi-dwelling houses modernization, Archives of Civil and Mechanical Engineering 13(1): 88-98. http://dx.doi.org/10.1016/j.acme.2012.11.003

Tamosaitiene, J.; Gaudutis, E. 2013. Complex assessment of structural systems used for high-rise buildings, Journal of Civil Engineering and Management 19(2): 305-317. http://dx.doi.org/10.3846/13923730.2013.772071

Turskis, Z.; Zavadskas, E. K. 2010. A new fuzzy additive ratio assessment method (ARAS-F). Case study the analysis of fuzzy multiple criteria in order to select the Logistic Centers location, Transport 25(4): 423-432. http://dx.doi.org/10.3846/transport.2010.52

Vinodh, S.; Varadharajan, A. R.; Subramanian, A. 2013. Application of fuzzy VIKOR for concept selection in an agile environment, The International Journal of Advanced Manufacturing Technology 65(5-8): 825-832. http://dx.doi.org/10.1007/s00170-012-4220-2

Yalcin, N.; Bayrakdaraglu, A.; Kahraman, C. 2012. Application of fuzzy multi-criteria decision making methods for financial performance evaluation of Turkish manufacturing industries, Expert Systems with Applications 39(1): 350-364. http://dx.doi.org/10.1016/j.eswa.2011.07.024

Yazdani, M.; Alidoosti, A.; Zavadskas, E. K. 2011. Risk analysis of critical infrastructures using fuzzy COPRAS, Ekonomska istrazivanja - Economic Research 24(4): 27-40.

Zavadskas, E. K.; Kaklauskas, A. 1996. Multiple criteria evaluation of buildings. Vilnius: Technika. 280 p.

Zavadskas, E. K.; Turskis, Z. 2011. Multiple criteria decision making (MCDM) methods in economics: an overview, Technological and Economic Development of Economy 17(2): 397-427. http://dx.doi.org/10.3846/20294913.2011.593291

Zavadskas, E. K.; Antucheviciene, J. 2007. Multiple criteria evaluation of rural building's regeneration alternatives, Building and Environment 42(1): 436-451. http://dx.doi.org/10.1016/j.buildenv.2005.08.001 


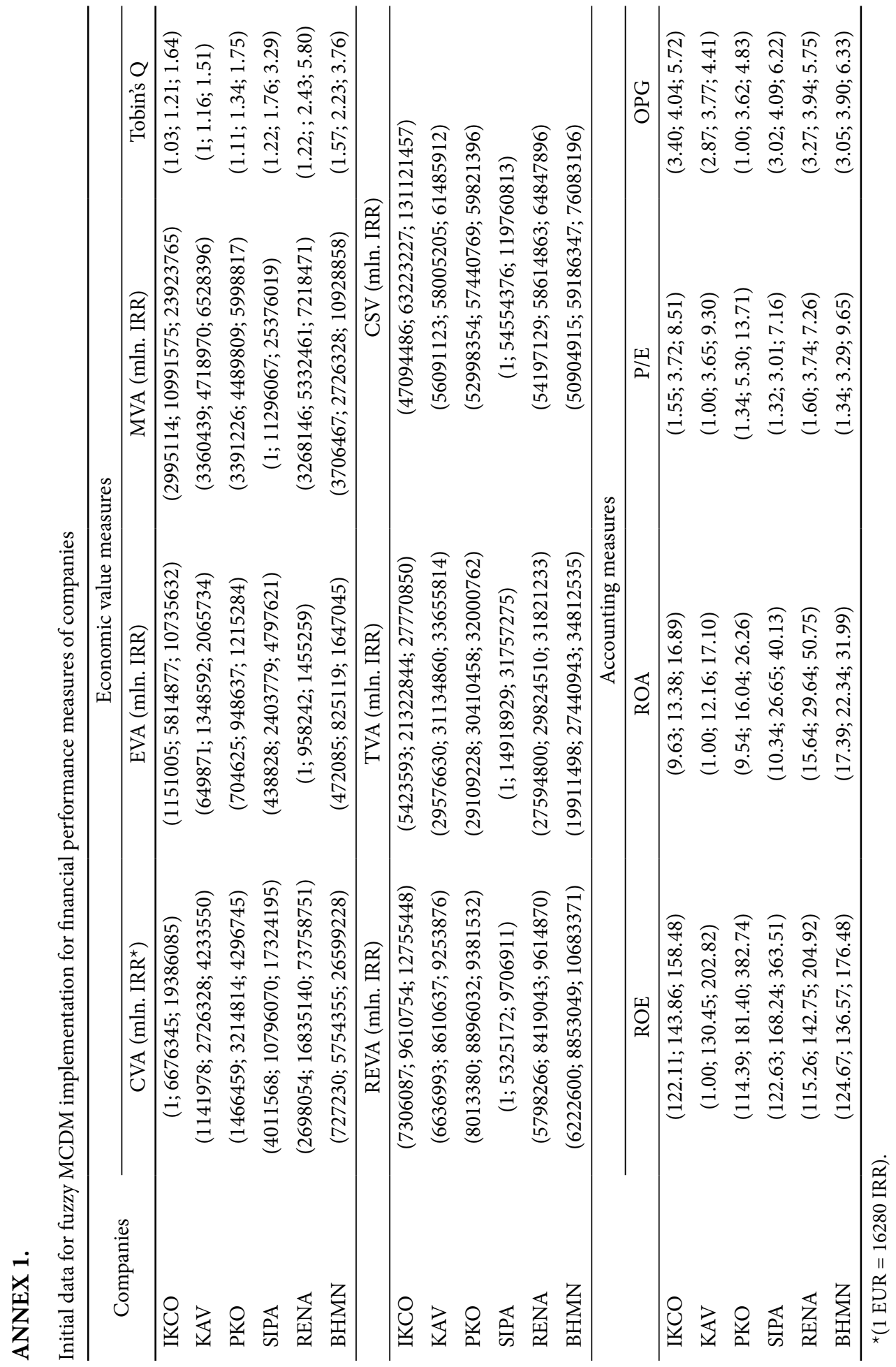


Abdolhamid SAFAEI GHADIKOLAEI. PhD in Operation Management, Assistant Professor at the Department of Industrial Management in University of Mazandaran. He is working as head of Khazar Nonprofit institution of higher education. His scientific interests cover areas of OR, decision-making theory, sustainable development, supply chain management, performance evaluation.

Saber KHALILI ESBOUEI. Master of Science of Operation Management at the Faculty of Economic and Administrative Sciences of University of Mazandaran. His scientific interests cover areas of OR, sustainable development, Decision-making theory, Supply chain management, financial performance evaluation.

Jurgita ANTUCHEVICIENE. Doctor, Assoc. Professor at the Department of Construction Technology and Management, Vilnius Gediminas Technical University, Lithuania. Research interests: sustainable development, construction business management and investment, multiple criteria analysis, decisionmaking theories and decision support systems. 